\title{
DAMPAK PENGUMUMAN HASIL PEMILU PRESIDEN REPUBLIK INDONESIA TAHUN 2019 TERHADAP SAHAM INDEKS IDX30
}

\section{THE IMPACT OF ANNOUNCEMENT OF THE PRESIDENTIAL ELECTION OF THE REPUBLIC OF INDONESIA 2019 ON IDX30 INDEX SHARES}

\author{
Devid Anggra Kurnia ${ }^{1}$, Sarah Usman ${ }^{2}$, Dirarini Sudarwadi ${ }^{3}$ \\ Universitas Papua ${ }^{1,2,3}$ \\ sarahlaode@gmail.com²
}

\begin{abstract}
This research examines the impact of the President and vice-Presidential 2019-2024 period election results against shares in the IDX30 index. The research aims to see the difference in the average trading volume activity shares between before and after the announcement. This research uses quantitative approaches with a comparative problem. The sample are all company shares included in the IDX30, actively traded and do not take corporate action at the time before and after the announcement of the President and Vice President. This research will compare the average trading volume acivity between before and after the announcement of the recapitulation results. Statistical testing is the Kolmogorov-Smirnov test, followed by a different test, the Paired Sample T-Test analysis test, the Wilcoxon Signed Rank analysis test. The result of the Wilcoxon signed rank test is $0.01<0.05$, which means the different trading volume activity is significant, the average is decrease. Investors are expected to consider buying shares after the announcement. This means that political events, namely the announcement of the recapitulation of the election of President and Vice President for the 2019-2024 period, affect the trading volume activity in the IDX30 index. For this reason, investors may consider buying shares after the announcement.
\end{abstract}

Keywords: Political Event, Trading Volume Activity

\begin{abstract}
ABSTRAK
Penelitian ini mengkaji dampak hasil pemilu Presiden dan Wakil Presiden periode 2019-2024 terhadap saham di indeks BEI 30. Penelitian ini bertujuan untuk melihat perbedaan rata-rata volume perdagangan saham antara sebelum dan sesudah pengumuman. Penelitian ini menggunakan pendekatan kuantitatif dengan masalah komparatif. Sampelnya adalah seluruh saham perusahaan yang masuk di BEI30, aktif diperdagangkan dan tidak melakukan aksi korporasi pada saat sebelum dan sesudah pengumuman Presiden dan Wakil Presiden. Penelitian ini akan membandingkan ratarata aktivitas volume perdagangan antara sebelum dan sesudah pengumuman hasil rekapitulasi. Pengujian statistik adalah uji Kolmogorov-Smirnov, dilanjutkan dengan uji beda, uji analisis Paired Sample T-Test, dan uji analisis Wilcoxon Signed Rank. Hasil uji Wilcoxon signed rank test adalah $0,01<0,05$ yang berarti perbedaan aktivitas volume perdagangan signifikan, rata-rata menurun. Investor diharapkan mempertimbangkan untuk membeli saham setelah pengumuman tersebut. Artinya, peristiwa politik yaitu pengumuman rekapitulasi hasil pemilihan Presiden dan Wakil Presiden periode 2019-2024 mempengaruhi aktivitas volume perdagangan di indeks
\end{abstract}


BEI. Untuk itu, investor bisa mempertimbangkan untuk membeli saham setelah pengumuman.

Kata Kunci: Peristiwa Politik, Aktivitas Volume Perdagangan

\section{PENDAHULUAN}

Melihat dari sudut pandang pasar modal, salah satu faktor yang dapat meningkatkan aktivitas di pasar modal adalah peristiwa politik dipublikasikan dalam bentuk pengumuman melalui berbagai media, baik media cetak maupun media elektronik. Menurut Jogiyanto (2017), Informasi-informasi yang menyebar di lingkungan pasar modal sangat memengaruhi kepekaan pasar modal terhadap harga saham yang kemudian akan berdampak pada return yang di hasilkan.

Salah satu peristiwa politik yang paling menyita perhatian adalah pengumuman Presiden dan Wakil Presiden terpilih periode 2019-2024 yang dilakukan pada tanggal 21 Mei 2019 dini hari. Padahal sebelumnya KPU menginformasikan bahwa pengumuman hasil rekapitulasi suara akan dilaksanakan pada tanggal 22 Mei 2019. Pengumuman yang dilakukan lebih awal dari rencana menimbulkan reaksi bagi pendukung pasangan calon Presiden dan Wakil Presiden tak terpilih, sehingga menimbulkan unjuk rasa yang berakhir ricuh.

Pengumuman hasil rekapitulasi juga dapat menimbulkan reaksi Investor sehingga berdampak bagi pasar modal Indonesia. Investor mengharapakan Presiden yang mampu menjaga kestabilan ekonomi Indonesia dimasa yang akan datang. Menurut Prabandari (2015), Jika hasil pemilu dipandang pelaku pasar sesuai dengan harapan, maka Investor akan kembali masuk ke bursa, bahkan akan berlomba menambah jumlah investasinya.
Salah satu indikator yang digunakan untuk menilai dampak peristiwa adalah trading volume activity. Menurut Beaver dalam Suganda (2018), aktivitas volume perdagangan saham (trading volume activity) merupakan the sum of Investor actions. Hal ini berarti bahwa aktivitas volume perdagangan saham (trading volume activity) merupakan titik temu antara sisi penawaran dan sisi permintaan. Dari pernayataan tersebut, dapat disimpulkan bahwa Pergerakan volume lembar saham yang ditransaksikan mencerminkan tingkah laku Investor.

Menurut Lestari (2017), Perkembangan volume perdagangan saham mencerminkan kekuatan antara penawaran dan permintaan yang merupakan manifestasi dari tingkah laku Investor. Naiknya volume perdagangan merupakan kenaikan aktivitas jual beli para Investor di bursa. Semakin meningkat volume penawaran dan permintaan suatu saham, semakin besar pengaruhnya terhadap pergerakan harga saham di bursa, dan semakin meningkatnya volume perdagangan saham menunjukkan semakin diminatinya saham tersebut oleh investor.

Penelitian ini menarik untuk dilakukan kembali dengan menguji peristiwa politik lainnya yaitu pengumuman hasil rekapitulasi pemilihan Presiden dan Wakil Presiden yang terjadi pada tanggal 21 Mei 2019. Penelitian ini bertujuan untuk melihat apakah terdapat perbedaan trading volume activity antara sebelum dan setelah peristiwa politik yaitu pengumuman hasil rekapitulasi 
pemilihan Presiden dan Wakil Presiden periode 2019-2024. Penelitian ini diharapkan dapat dijadikan referensi untuk penelitian selanjutnya dan dapat dijadikan tambahan informasi bagi Investor di pasar modal untuk pengambilan keputusan investasi.

\section{METODE PENELITIAN}

Penelitian ini akan dilakukan pada saham-saham yang terdaftar dalam indeks IDX30 di Bursa Efek Indonesia. Pengambilan data diambil di Galeri Investasi Universitas Papua. Pendekatan pada penelitian ini menggunakan pendekatan kuantitatif dengan jenis masalah komparatif.

Data yang digunakan dalam penelitian ini adalah data sekunder yang bersumber dari Bursa Efek Indonesia dalam webnya yaitu www.idx.co.id. Data sekunder yang diperlukan dalam penelitian ini adalah data-data perdagangan saham harian perusahaan yang terdaftar dalam indeks IDX30 yang melakukan transaksi di Bursa Efek Indonesia (BEI) pada saat sebelum hingga setelah peristiwa pengumuman hasil rekapitulasi pemilihan Presiden dan Wakil Presiden Periode 2019-2024.

Populasi dalam penelitian ini adalah seluruh saham perusahaan yang masuk dalam indeks IDX30 yang aktif diperdagangkan dan tidak melakukan aksi korporasi pada saat sebelum dan setelah peristiwa pengumuman Presiden dan Wakil Presiden. Metode sampling yang digunakan pada penelitian ini adalah metode nonprobability sampling dengan menggunakan teknik sampling jenuh.

Penelitian ini akan membandingkan rerata rerata trading volume acivity antara sebelum dan setelah peristiwa pengumuman hasil rekapitulasi pemilihan Presiden dan Wakil Presiden periode 2019-2024 untuk melihat apakah peristiwa tersebut memberi dampak yang signifikan trading volume acivity pada indeks IDX30.

Metode analisis data pada penelitian ini mengikuti langkah-lagkah sebagaimana dikemukakan oleh Jogiyanto (2018) dengan beberapa modifikasi sebagai berikut:

1. Menentukan Peristiwa yang akan diteliti dan dilihat reaksi pasarnya. Peristiwa yang akan diteliti yaitu pengumuman hasil rekapitulasi pemilihan Presiden dan Wakil Presiden periode 2019-2024.

2. Mengidentifikasi persitiwa dan tanggal terjadinya peristiwa. Pengumuman hasil rekapitulasi pemilihan Presiden dan Wakil Presiden periode 2019-2024 termasuk kedalam persitiwa politik dan terjadi pada tanggal 21 Mei 2019.

3. Menentukan panjang periode pengamatan. Periode pengamatan pada penelitian ini adalah 7 hari yaitu, 3 hari sebelum peristiwa, 1 hari saat terjadinya peristiwa, dan 3 hari setelah terjadinya peristiwa.

4. Mengeluarkan peristiwa pengganggu. Selama periode pengamatan, tidak ditemukan peristiwa lain yang akan memengaruhi aktivitas perdagangan saham.

5. Menghitung trading volume activity saham sebagai berikut:

${ }^{T V} A_{i t}$
$=\frac{\sum \text { saham i ditransaksikan pada waktu ke } t}{\sum \text { saham i beredar pada waktu ke } t}$

Data yang terkumpul selanjutnya dianalisis secara bertahap. Tahap pertama dilakukan analisis statistik deskriptif terlebih dahulu, setelah itu dilakukan pengujian statistik yaitu uji distribusi normal dengan menggunakan uji kolmogorov-smirnov, data dikatakan 
berdistribusi normal apabila asymptotic sig $>$ tingkat keyakinan yang digunakan dalam pengujian, dalam hal ini adalah $95 \%$ atau $\alpha=5 \%$.

Kemudian tahap selanjutnya dilakukan pengujian dengan menggunakan uji beda. Apabila data berdistribusi normal, maka data diuji menggunakan uji analisis Paired Sample T-Test, terdapat perbedaan yang signifikan antara sebelum dan setelah persitiwa apabila nilai signifikansi < 0,05 . Apabila data tidak berdistribusi normal, maka digunakan uji analisis Wilcoxon Signed Rank, terdapat perbedaan yang signifikan antara sebelum dan setelah persitiwa apabila signifikansi $<0,05$.

\section{HASIL DAN PEMBAHASAN Analisis Statistik Deskriptif}

Hasil rekap data aktivitas volume perdagangan saham (trading volume activity) harian selama periode pengamatan dapat dilihat pada gambar 1 sebagai berikut:

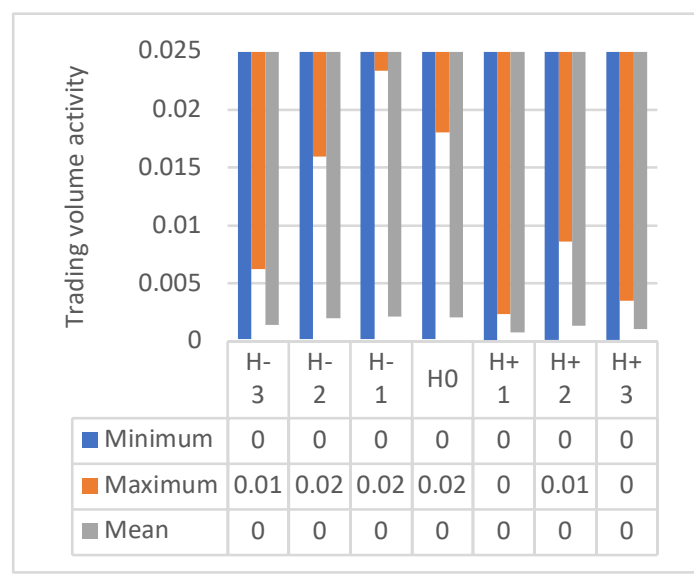

Sumber : Data sekunder diolah 2020

Gambar 1. Grafik Rerata Abnormal Return Selama Pengamatan

Pergerakan aktivitas volume perdagangan saham (trading volume activity) meningkat seiring semakin dekatnya pengumuman hasil rekapitulasi pemilihan Presiden dan Wakil Presiden periode 2019-2024, pergerakan tersebut dapat dilihat pada gambar 1. Aktivitas volume perdagangan saham (trading volume activity) terendah sebelum pengumuman terjadi pada tanggal 16 Mei 2019 (H-3) dengan rerata trading volume activity sebesar 0,00143 atau 0,14 . Sedangkan aktivitas volume perdagangan saham (trading volume activity) tertinggi sebelum pengumuman terjadi pada tanggal 20 Mei 2019 (H-1) dengan rerata trading volume activity sebesar 0,00212 atau 0,21.

Setelah peristiwa terjadi, aktivitas volume perdagangan saham (trading volume activity) saham mengalami penurunan pada tanggal 22 Mei $2019(\mathrm{H}+1)$, kemudian setelah itu aktivitas volume perdagangan saham (trading volume activity) mengalami fluktuasi namun cenderung menunjukkan peningkatan hingga $\mathrm{H}+3$. Aktivitas volume perdagangan saham (trading volume activity) terendah setelah pengumuman terjadi pada tanggal 22 Mei $2019(\mathrm{H}+1)$ dengan rerata trading volume activity sebesar 0,00081 atau $0,08 \%$. Sedangkan aktivitas volume perdagangan saham (trading volume activity) tertinggi setelah pengumuman terjadi pada tanggal 23 Mei $2019(\mathrm{H}+2)$ dengan rerata trading volume activity sebesar 0,00139 atau $0,14 \%$.

\section{Uji Normalitas}

Uji normaliitas pada penelitian ini bertujuan untuk menentukan teknik pengujian yang dipakai pada analisis perbandingan. Adapun pengujian dari setiap data yang digunakan dalam penelitian ini dapat dilihat pada tabel 1 sebagai berikut: 
Tabel 1. Uji Normalitas

\begin{tabular}{|c|c|c|c|}
\hline \multicolumn{4}{|c|}{ Kolmogorov-Smirnova } \\
\hline & Statistic & $\mathrm{df}$ & Sig. \\
\hline $\begin{array}{l}\text { ATVA } \\
\text { Sebelum- } \\
\text { ATVA } \\
\text { Setelah }\end{array}$ & 0,424 & 30 & 0,000 \\
\hline
\end{tabular}

Dari tabel di atas, rerata aktivitas volume perdagangan saham (trading volume activity) sebelum dan setelah peristiwa memiliki nilai signifikasi (Asymp. Sig.) sebesar $0,000<0,05$, dengan demikian data aktivitas volume perdagangan saham (trading volume activity) dalam penelitian ini tidak berdistribusi normal, maka selanjutnya akan dilakukan uji analisis perbandingan dengan menggunakan uji wilcoxon signed rank test.

\section{Analisis Perbandingan}

Pengujian dalam penelitian ini menggunakan uji paired sample T-test untuk menganalisis abnormal return. Hasil analisis perbandingan antara aktivitas volume perdagangan saham (trading volume activity) sebelum peristiwa dan setelah peristiwa dapa dilihat pada tabel 2 sebagai berikut:

Tabel 2. Uji Wilcoxon Signed Rank Test

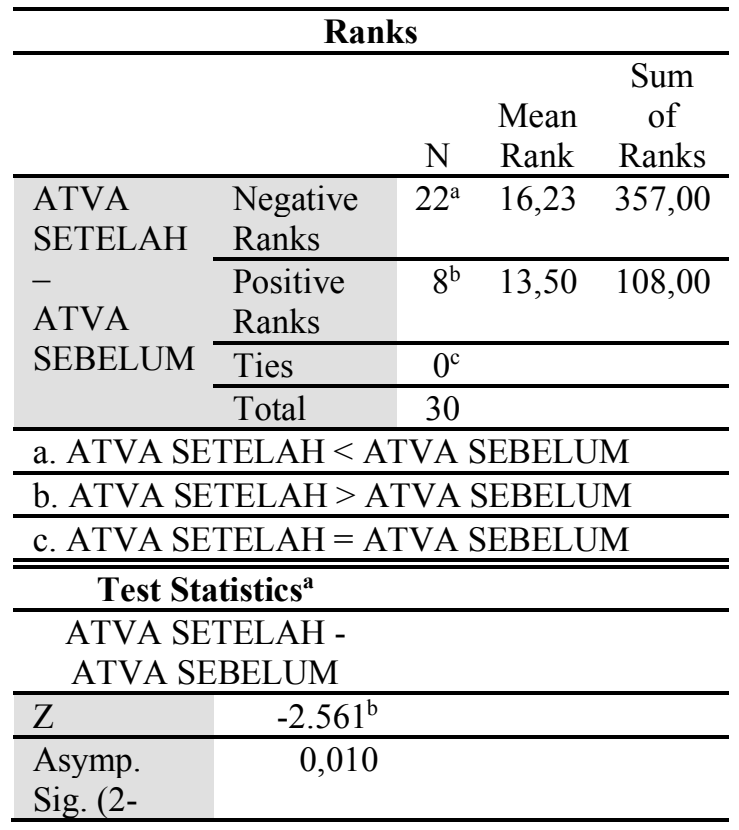

\begin{tabular}{l}
\hline tailed) \\
\hline a. Wilcoxon Signed \\
Ranks Test \\
\hline b. Based on positive \\
ranks. \\
\hline Sumber : Data sekunder diolah 2020
\end{tabular}

Hasil uji wilcoxon signed ranks test menunjukkan nilai probabilitas $\mathrm{z}$ hitung (Asymp. Sig.) rerata aktivitas volume perdagangan saham (trading volume activity) sebesar 0,010 atau $1,0 \%$, lebih kecil dari taraf signifikansi sebesar 0,05 atau 5\%. Hal ini menunjukkan bahwa terdapat perbedaan yang signifikan rerata aktivitas volume perdagangan saham (trading volume activity) antara sebelum dan setelah peristiwa pengumuman hasil rekapitulsai pemilihan Presiden dan Wakil Presiden periode 2019-2024

Berdasarkan hasil penelitian, saham perusahaan yang masuk dalam indeks IDX30 memiliki perbedaan rerata aktivitas volume perdagangan saham (trading volume activity) yang signifikan antara sebelum dan setelah peristiwa. Hal ini dibuktikan dengan uji wilcoxon signed rank test yang menghasilkan nilai probabilitas $\mathrm{z}$ hitung sebesar 0,010, lebih kecil dari taraf signifikansi sebesar 0,05 . Hal ini berarti bahwa peristiwa pengumuman hasil rekapitulasi pemilihan Presiden dan Wakil Presiden periode 2019-2024 memberikan dampak yang besar bagi aktivitas volume perdagangan saham yang dilakukan oleh Investor.

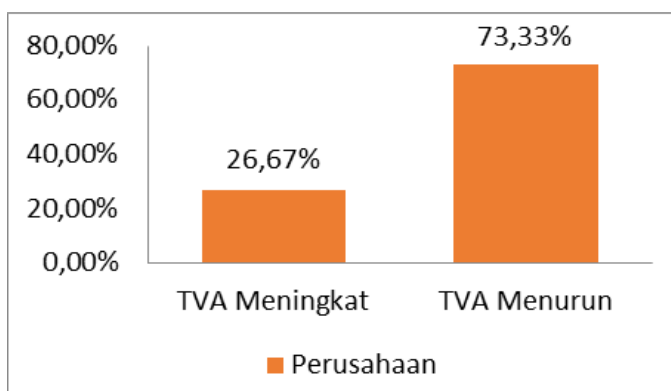

Gambar 2. Diagram Trading Volume Activity 
Dari 30 saham yang diteliti, hanya $26,67 \% \quad$ (8) perusahaan menunjukkan peningkatan aktivitas volume perdagangan saham (trading volume activity) setelah pengumuman, sedangkan terdapat $73,33 \% \quad$ (22) perusahaan menunjukkan penurunan aktivitas volume perdagangan saham (trading volume activity) setelah peristiwa. Penurunan aktivitas volume perdagangan saham (trading volume activity) menunjukkan penurunan minat Investor untuk melakukan transaksi setelah pengumuman. Perubahan aktivitas volume perdagangan saham (trading volume activity) saham sangat dipengaruhi oleh minat Investor untuk melakukan transaksi. Menurut Lestari (2017), semakin meningkatnya volume perdagangan saham menunjukkan semakin diminatinya saham tersebut oleh masyarakat

Sektor saham perusahaan yang mengalami penurunan aktivitas volume perdagangan saham (trading volume activity) terbesar adalah sektor industri barang konsumsi yaitu sebesar $22,72 \%$ (5) perusahaan dari total perusahaan yang mengalami penurunan. Penurunan ini dipicu oleh adanya unjuk rasa yang berakhir ricuh setelah pengumuman hasil rekapitulasi pemilihan presdien dan wakil presiden dilaksanakan.

Perusahaan-perusahaan pada sektor industri barang kosumsi adalah perusahaan yang memproduksi barangbarang konsumsi yang sehari-hari digunakan oleh masyarakat. Terjadinya unjuk rasa yang berakhir ricuh menyebabkan menurunnya minat beli masyarakat sehingga mempengaruhi kepercayaan Investor untuk melakukan investasi pada sektor industri barang konsumsi. Investor saham pada sektor industri barang dan konsumsi lebih memilih untuk mengurangi transaksi di pasar modal dan menunggu terlebih dahulu hingga situasi benar-benar kondusif sampai pelaksanaan pelantikan Presiden dan Wakil Presiden.

Selain mengalami penurunan, terdapat saham perusahaan yang mengalami peningkatan aktivitas volume perdagangan saham (trading volume activity), sektor dengan jumlah saham terbanyak yang mengalami kenaikan yaitu sektor pertambangan, sektor keuangan, dan sektor industri dasar dan kimia masing-masing sebesar $25 \%$ (2) perusahaan dari seluruh perusahaan yang mengalami peningkatan. Hal ini menunjukkan bahwa saham perusahaan pada sektor pertambangan, sektor keuangan, dan sektor industri dasar dan kimia setelah pengumuman mulai diminati Investor. Terdapat beberapa faktor yang menyebabkan perusahaan diminati oleh Investor, salah satu faktor tersebut adalah harga saham yang dianggap terjangkau oleh Investor.

\section{PENUTUP \\ Kesimpulan}

Berdasarkan pembahasan tentang dampak peristiwa politik yaitu pengumuman hasil rekapitulasi pemilihan Presiden dan Wakil Presiden periode 2019-2024 terhadap saham dalam indeks IDX30, dapat disimpulkan bahwa terdapat perbedaan aktivitas volume perdagangan saham (trading volume activity) yang signifikan antara sebelum dan setelah peristiwa. Hasil uji wilcoxon signed rank test menunjukkan nilai probabilitas z hitung sebesar 0,010 , lebih kecil dari taraf signifikansi sebesar 0,05 . Artinya bahwa peristiwa politik yaitu pengumuman hasil rekapitulasi pemilihan Presiden dan Wakil Presiden periode 2019-2024 berpengaruh bagi aktivitas volume perdagangan saham (trading volume activity) dalam indeks IDX30. Dari hasil penelitian dapat dilihat bahwa rerata aktivitas volume perdagangan saham (trading volume 
activity) setelah peristiwa mengalami penurunan, sehingga dapat dikatakan bahwa peristiwa yang terjadi memberikan dampak yang negatif terhadap aktivitas perdagangan saham yang dinilai dari aktivitas volume perdagangan saham (trading volume activity). Rerata aktivitas volume perdagangan saham (trading volume activity) terendah terjadi pada tanggal 22 Mei $2019(\mathrm{H}+1)$ yaitu sebesar 0,00081 atau $0,08 \%$, sedangkan rerata aktivitas volume perdagangan saham (trading volume activity) tertinggi terjadi pada tanggal 20 Mei 2019 (H-1) yaitu sebesar 0,00212 atau $0,21 \%$.

\section{Saran}

Bagi Investor disarankan untuk dapat mempertimbangkan dalam melakukan pembelian saham setelah pegumuman, hal ini dikarenakan terdapat penurunan minat investor untuk melakukan transaksi setelah pengumuman terjadi.

Bagi peneliti selanjutnya diharapkan dapat mengukur reaksi pasar modal dengan menambahkan variabel lain selain aktivitas volume perdagangan saham (trading volume activity), seperti abnormal return, bid/ask spread dan frekuensi perdagangan saham untuk memperkaya hasil penelitian.

\section{DAFTAR PUSTAKA}

Jogiyanto. (2017). Teori Portofolio dan analisis investasi. Yogyakarta: BPFE

Jogiyanto. (2018). Studi Peristiwa: Menguji Reaksi Pasar Modal Akibat Suatu Peristiwa. Yogyakarta: BPFE

Lestari, M.,A. (2017). Reaksi Pasar Modal Indonesia Terhadap Terpilihnya Donald Trump. Skripsi. Batam: Polibatam
Prabandari, M. (2015). Dampak Pengumuman Kemenangan Jokowi Pada Pemilihan Umum Presiden $2014 \quad$ Terhadap Abnormal Return Saham Lq 45 Di Bursa Efek Indonesia. Skripsi. Universitas Negeri Yogyakarta. Yogyakarta

Suganda, T.,R. (2018). Event study: teori dan pembahasan reaksi pasar modal Indonesia. Seribu Bintang. 